University of Nebraska - Lincoln

DigitalCommons@University of Nebraska - Lincoln

Faculty Publications from the Harold W. Manter Laboratory of Parasitology

$2-1-2000$

\title{
Helminthoxys abrocomae n. sp. (Nematoda: Oxyurida) from Abrocoma cinerea in Bolivia
}

\author{
Jean-Pierre Hugot \\ Museum National d'Histoire Naturelle \\ Scott Lyell Gardner \\ University of Nebraska - Lincoln, slg@unl.edu
}

Follow this and additional works at: https://digitalcommons.unl.edu/parasitologyfacpubs

Part of the Parasitology Commons, and the Zoology Commons

Hugot, Jean-Pierre and Gardner, Scott Lyell, "Helminthoxys abrocomae n. sp. (Nematoda: Oxyurida) from Abrocoma cinerea in Bolivia" (2000). Faculty Publications from the Harold W. Manter Laboratory of Parasitology. 55.

https://digitalcommons.unl.edu/parasitologyfacpubs/55

This Article is brought to you for free and open access by the Parasitology, Harold W. Manter Laboratory of at DigitalCommons@University of Nebraska - Lincoln. It has been accepted for inclusion in Faculty Publications from the Harold W. Manter Laboratory of Parasitology by an authorized administrator of DigitalCommons@University of Nebraska - Lincoln. 
Published in Systematic Parasitology (2000) 47: 223-230.

Copyright 2000, Kluwer Academic Publishers. Used by permission.

\title{
Helminthoxys abrocomae n. sp. (Nematoda: Oxyurida) from Abrocoma cinerea in Bolivia
}

\author{
Jean-Pierre Hugot ${ }^{1} \&$ Scott L. Gardner ${ }^{2}$
}

\begin{abstract}
${ }^{1}$ Muséum National d'Histoire Naturelle, Institut de Systématique, FR 1541 CNRS, Laboratoire de Zoologie des Mammifères et Oiseaux (Biosystématique et Coèvolution chez les Nématodes Parasites), 55, rue Buffon, 75231 Paris cedex 05, France

${ }^{2}$ Harold W. Manter Laboratory of Parasitology, University of Nebraska State Museum, W529, Nebraska Hall, Lincoln, Nebraska 68588-0514, USA (slg@unl.edu)
\end{abstract}

Accepted for publication January, 24, 2000.

\begin{abstract}
Anew pinworm parasite is described from Abrocoma cinerea, a caviomorph rodent of the superfamily Octodontoidea from the Andes of Bolivia. The new species, Helminthoxys abrocomae n. sp., possesses special secretory mamelons which we consider a synapomorphy of the genus Helminthoxys. Within Helminthoxys, the closest relatives are found in octodontoid rodents: $\mathrm{H}$. gigantea occurs in Octodon degus in Chile and O. bridgesi in Argentina, and $H$. freitasi is a parasite of Thrichomys aperoides in Brazil. H. abrocomae n. sp. differs from both other species morphometrically in relation to different parts of the body in both sexes, particularly the size of the body, spicule, gubernaculumand eggs, by the presence of a rough cuticular area around the cephalic sensory papillae and by the possession of very well-developed cervical alae which are strongly curved dorsally. H. abrocomae $\mathrm{n}$. sp. is the tenth nominal species described in Helminthoxys, all of them being parasites of caviomorph rodents.
\end{abstract}

\section{Introduction}

Herein we provide the description of a new species of nematode of the family Oxyuridae and genus Helminthoxys Freitas, Lent \& Almeida, 1937 recovered from the caecum of individuals of Abrocoma cinerea (Thomas) (Rodentia: Caviomorpha) collected from the Andes of Bolivia.

\section{Materials and methods}

Mammals were collected in live-traps, killed with chloroform and examined for helminths within a few minutes of death. Pinworms were collected from the large intestine and caecum, and either placed directly in $10 \%$ formalin or plunged into glacial acetic acid for a few seconds prior to fixation in $10 \%$ formalin. Some specimens were preserved in either $95 \%$ ethanol or liquid nitrogen for future analyses of genetic material. Specimens were studied under the light microscope as temporary wet mounts, first in water and later in lactophenol. We studied hand-cut cross-sections made using small pieces of razor-blade and a small brush. Drawings were made with the aid of a drawing tube.

\section{Helminthoxys abrocomae n. sp.}

\section{Description}

Holotype male. Width gradually increasing posterior to cephalic vesicle, reaching maximum at level of mid-body. Tail short, with slender tip (Figure 1A). Mouth surrounded by 3 prominent pseudolabia (sensu Hugot, 1988); on each dorso-lateral pseudolabia 2 labial papillae are closely grouped laterally with corresponding amphid, all of them being surrounded by rough cuticular area (Figure 1B, C, E); 3 strong conical oesophageal teeth are intercalated with cuticularised thickenings of inner part of pseudolabia (Figure 1B, D, F). Ventral pseudolabium cap-shaped (Figure 1E, F); dorsolateral pseudolabia bowed dorsally, each being prolonged laterally by voluminous protuberance 


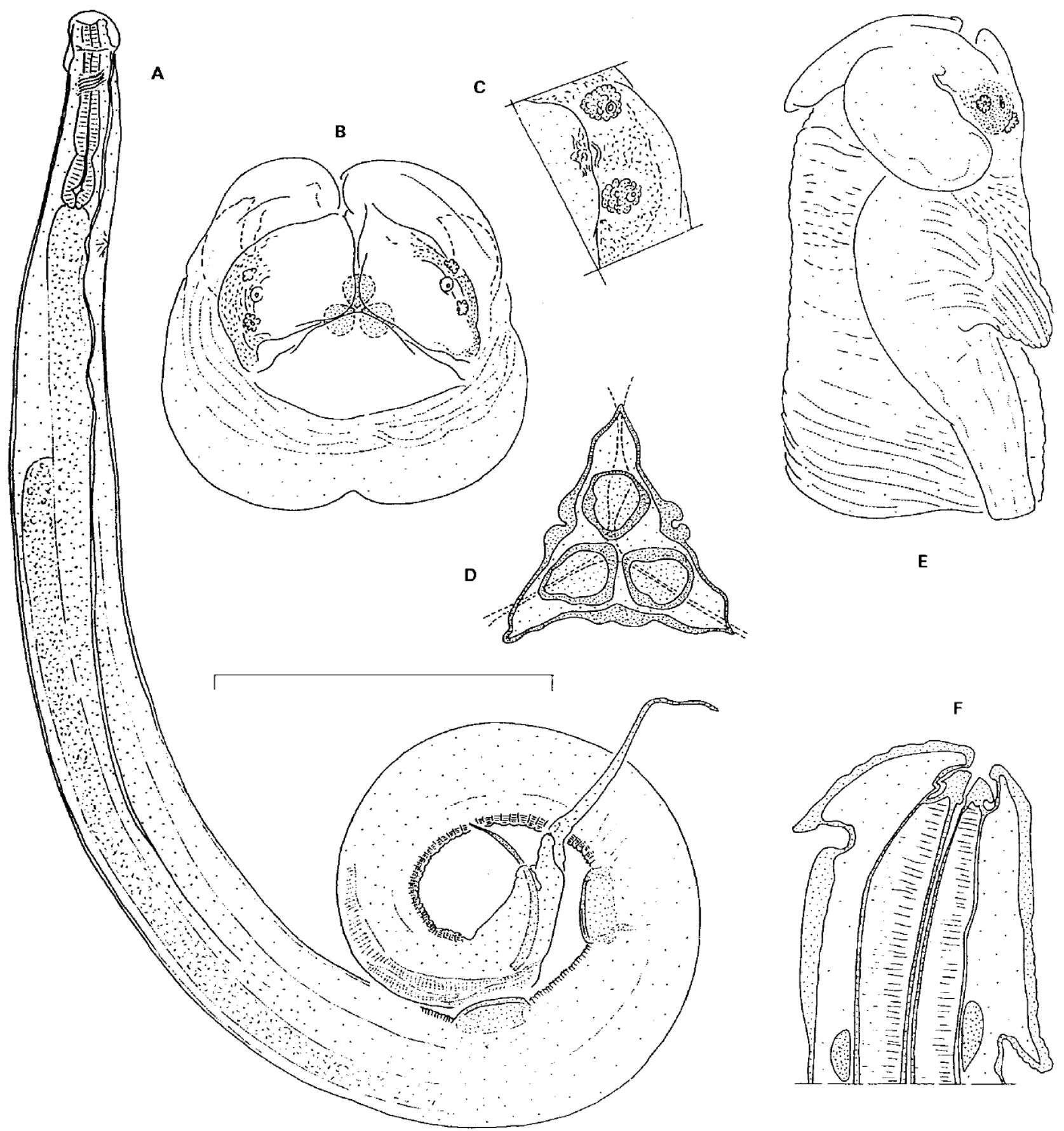

Figure 1. Helminthoxys abrocomae n. sp., holotype male. A, entire worm, right lateral view; B, head, apical view; C, idem, detail of the sensory organs of the left side; D, optical section of the oesophageal teeth in apical view; E, left lateral view of the anterior region of the body; F, idem, optical sagittal section. Scale-bar: A, 1,650 $\mu \mathrm{m} ; \mathrm{B}, \mathrm{E}, \mathrm{F}, 250 \mu \mathrm{m} ; \mathrm{C}, \mathrm{D}, 100 \mu \mathrm{m}$. 
gradually giving rise to strong cervical ala, triangular on a cross-section and curved dorsally (Figures 1B, E, 2A). Size of cervical alae decreases posteriorly as they progressively transform into small, sharp lateral alae, ending just anterior to cloaca (Figures 1A, 2B, 3F). Excretory pore close to posterior end of oesophagus. Monorchic, with testis reflexing at about twice length of oesophagus from anterior extremity (Figure 1A). Area rugosa composed of 2 ventro-medial mamelons, followed by regular ranks of small longitudinal crests corresponding with cuticular striae (Figure 1A). Each mamelon with 5 secretory slots corresponding with ventral cuticular striae of body (Figure 2D, E). Secretory slots communicating with gland formed by local differentiation of ventral hypodermis. At level of mamelons ventral myocytes appear transformed: they are hypertrophied and orientation of myofibrils is modified to allow conduction of secretions from gland during mating (Figure 2B, C, F). Ranks of crests extend from end of second mamelon to last cuticular striation before caudal bursa (Figures 1A, 3E); size of crests decreases from ventro-median line laterally; crests oriented toward right side of body; external and internal layers of cuticle supporting crests are separated and interstitial space filled with liquid (Figure $3 \mathrm{~F}, \mathrm{G})$. Genital papillae: 3 pairs (Figure 3A), comprising 2 pairs lateral, adanal and sessile (Figure $3 \mathrm{~B}, \mathrm{C}$ ) and one pair posterior and pedunculate, flanking base of tail-tip. Phasmids situated laterally and posterior to last pair of caudal papillae. Spicule curved ventrally, well cuticularised, with sharp tip (Figure 1A). Gubernaculum present, well developed (Figure 3D), with accessory hook (cuticularised posterior lip of cloaca) twisted toward right side of body, thick and covered with scale-shaped ornamentation (Figure 3B, C, D).

Allotype female. Long worm with inflated cephalic vesicle; body narrowing just posterior to vulva and terminating in short tail (Figure $4 \mathrm{~A}$ ). Buccal structures, cephalic vesicle and cervical alae as in males (Figure 4A, C). Excretory pore situated at about twice length of oesophagus from anterior extremity; vulva situated at limit of first and second thirds of body. Genital tract didelphic and symmetrical, with oviducts making loops around voluminous spermatheca (Figure $4 \mathrm{E})$. Spermatheca with inner epithelium modified, its cells being tall and narrow, separated from lu- men of oviduct by several larger cells which obstruct its opening (Figure 4F). Eggs lemon-shaped, thin-shelled and unembryonated (Figure 4D).

Measurements. See Table 1.

\section{Diagnosis}

General: Large worms with 3 prominent pseudolabia; labial papillae closely grouped laterally with corresponding amphid, surrounded by rough cuticular area; pseudolabia prolonged laterally by voluminous protuberances giving rise to well-developed cervical alae which are strongly curved dorsally. Male. Area rugosa composed of 2 ventral secretory mamelons followed by regular ranks of crests oriented toward right side of body. Three pairs of genital papillae. Spicule well-sclerotised, with sharp tip. Accessory hook of gubernaculum twisted toward right side of body, thick and covered with a scale-shaped ornamentation. Female. Eggs lemon-shaped, thin-shelled and unembryonated.

Symbiotype: Abrocoma cinerea (Thomas) adult male, Museum of Southwestern Biology (MSB) catalogue no. 70580; field collection no. SLG155-93; MSB Division of Biological Materials, New Mexico Kryovoucher no. NK30666. Parasymbiotypes: Abrocoma cinerea adult female no. NK30665, and lactating adult female no. NK30667. Site in host: Caecum and colon. Type-locality and date of collection: $11.5 \mathrm{~km}$ west of San Andrès de Machaca, Departamento de La Paz, Bolivia, 16 $59^{\prime} 47^{\prime \prime} S$, 6903'31"W, elevation 3,850 m, 3 August 1993. Holotype male and allotype female: Harold W. Manter Laboratory of Parasitology Collection (HWML) no. NK30666 and MSB, New Mexico Kryovoucher no. NK22814 A, respectively. Paratypes: Muséum National d'Histoire Naturelle, Paris, (MNHN no. $79 \mathrm{KJ}) 3$ males and 3 females, and (MNHN no. $80 \mathrm{KJ}$ ) 3 males and 3 females.

\section{Discussion}

In addition to the new species described herein, the genus Helminthoxys includes seven species, all parasite of caviomorph rodents. The type-species, $H$. caudatus Freitas, Lent \& Almeida, 1937, has been reported from the caviid Microcavia australis (I. Geoffroy \& d'Orbigny) in Argentina. H. velizy Parra 

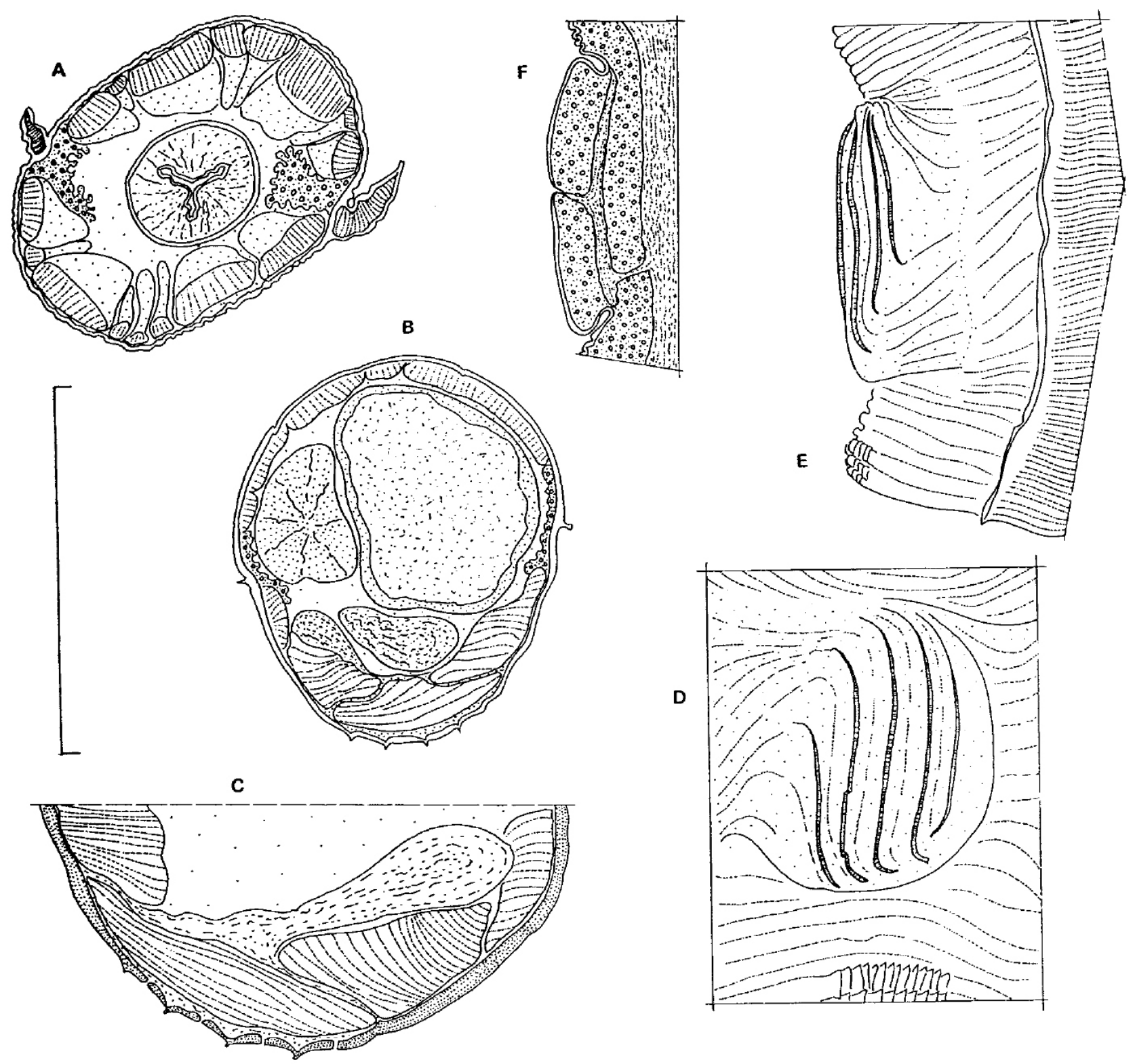

Figure 2. Helminthoxys abrocomae n. sp., holotype male. A, cross-section of the body at the level of the cervical alae, posterior view; $\mathrm{B}$, cross-section of the body at level of the first mamelon; C, idem, detail; D, second mamelon ventral view; E, idem, left lateral view; F, idem, optical sagittal section. Scale-bar: A, B, $250 \mu \mathrm{m} ; \mathrm{C}-\mathrm{F}, 50 \mu \mathrm{m}$.

Ormeño, 1953 is specific to the chinchillid Lagidium peruanum Meyen in Bolivia and Peru. The other five, including $H$. abrocomae n. sp., are specific to members of the Octodontoidea, including $H$. freitasi Quentin, 1969 from Trichomys aperoides Lund in Brazil, H. gigantea (Quentin, Courtin \& Fontecilla, 1975) from Octodon degus (Molina) in Chile and O. bridgesi Waterhouse in Argentina (Sutton \& Hugot, 1993), H. quentini Barus, 1972 from Capromys pilorides
(Say) in Cuba and H. tiflophila (Vigueras, 1943) from Mysateles prehensilis Poeppig in Cuba. Lastly, H. urichi Cameron \& Reesal, 1951 occurs thus far only in Dasyprocta aguti (L.), a member of the Dasyproctidae, in Trinidad and French Guyana (Hugot, 1986). Two additional species, H. pujoli Quentin, 1973, a parasite of the Bolivian caviid Microcavia niata (Thomas), and H. effilatus Schuurmans-Stekhoven, 1951, from Lagidium viscacia boxi Thomas 

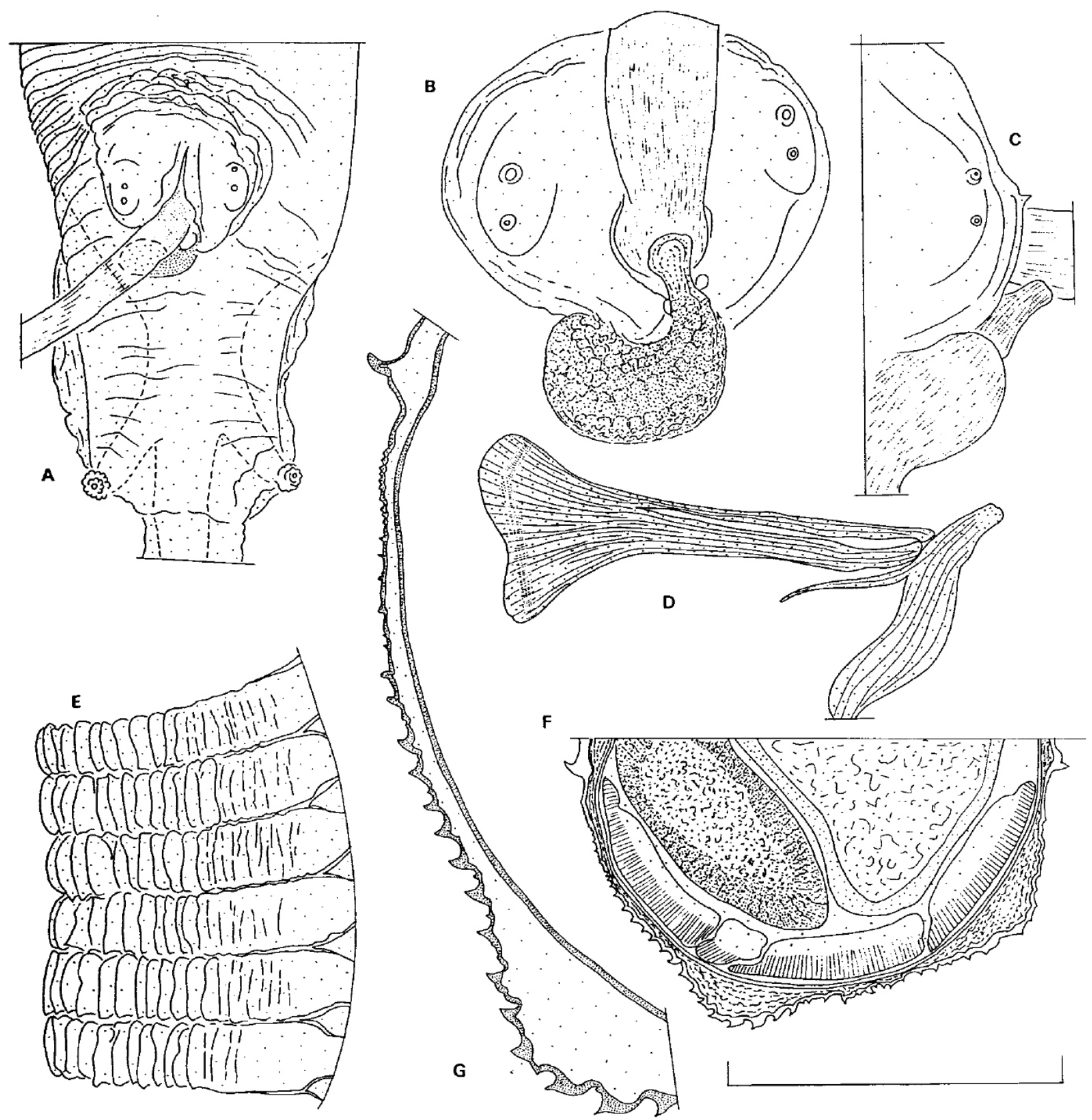

Figure 3. Helminthoxys abrocomae n. sp., holotype male. A, bursal cauda, ventral view; B, idem, detail of the cloacal opening; C, idem, detail on a right lateral view; $\mathrm{D}$, gubernaculum, right lateral view; $\mathrm{E}$, area rugosa posterior to second mamelon, left lateral

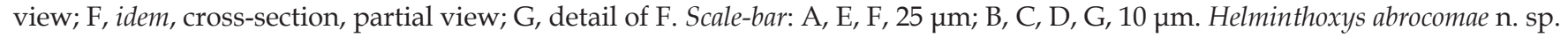

in Argentina, were synonymised with $H$. pujoli and H. velizi, respectively (Hugot \& Sutton, 1989). Helminthoxys abrocomae n. sp.

Our specimens possess the special secretory mamelons which we considered synapomorphies for Helminthoxys (see Hugot, 1983, 1988), thus justifying inclusion of these specimens in this genus.
Within Helminthoxys, only $H$. gigantea and $H$. freitasi exhibit a buccal structure similar to $H$. abrocomae $\mathrm{n}$. sp., with dorso-lateral pseudolabia bowed dorsally and prolonged laterally by voluminous protuberances giving rise to the cervical alae. $H$. abrocomae $\mathrm{n}$. sp. can be distinguished from $H$. freitasi by the following: having a larger body size in both male and female; an excretory pore situated relatively 

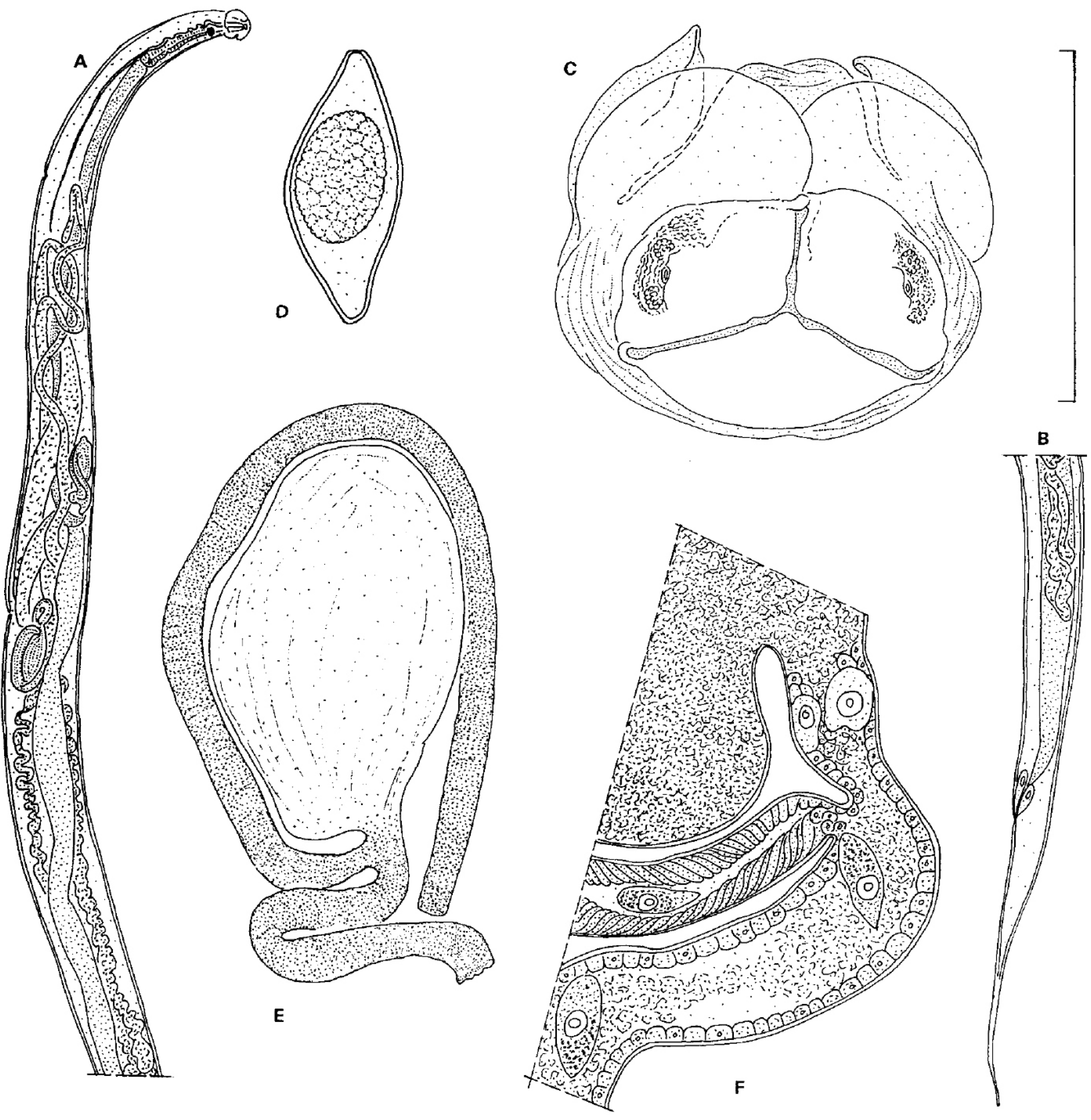

Figure 4. Helminthoxys abrocomaen. sp., allotypefemale. A,B, entireworm, leftlateral view; C, head, apical view; D, egg; E, spermatheca after dissection. F, idem, detail. Scale-bar: A,B, $415 \mu \mathrm{m} ; \mathrm{C}, \mathrm{F}, 25 \mu \mathrm{m} ; \mathrm{D}, 10 \mu \mathrm{m} ; \mathrm{E}, 50 \mu \mathrm{m}$.

more anteriorly; a relatively longer oesophageal bulb; a relatively shorter spicule and relatively longer gubernaculum in males; and in females a vulva situated in the anterior half of the body (Table 1), the presence of a rough cuticular area around the cephalic sensory organs and a more rounded cephalic plate. The new species most closely resembles $H$. gigantea in the following: (i) lemon-shaped, thin-shelled eggs (in other species of the genus the eggs generally are reniform and thick-shelled); (ii) a relatively weak development of the lateral adanal caudal papillae in males; (iii) the presence of a rough cuticular area around the cephalic sensory organs; and (iv) generally similar measurements of the different parts of the body, especially in the females (Table 1). However, H. abrocomae n. sp. can be distinguished from $H$. gigantea by the larger size of both sexes, a relatively more anteriorly sit- 
Table 1. Measurements in micrometres of male and female of Helminthoxys abrocomae n. sp., plus H. gigantea (Quentin, Courtin \& Fontecilla, 1975) and $H$. freitasi Quentin, 1969, from their original descriptions. Plain text represent measurements, italics indicate ratios and bold text represents values that provide good separation between H. abrocomae n. sp. and one or both of the other species.

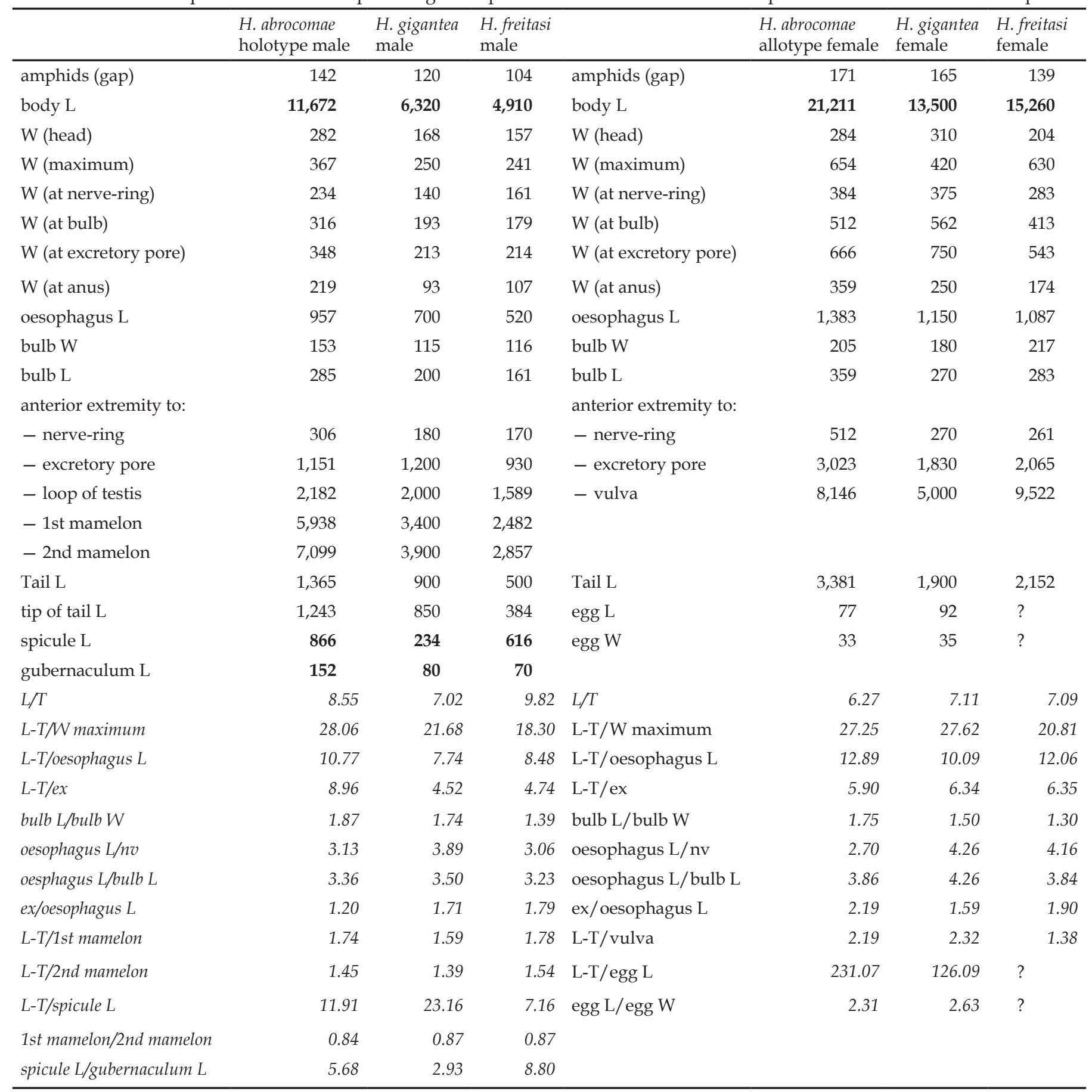

Abbreviations: L, length; W, width; T, tail length; L-T, bodylength minus tail length; nv, ex, 1st mamelon, 2nd mamelon, vulva=distance fromanterior extremity to nerve-ring; excretory pore, first amd second mamelon, or vulva, respectively; ?, missing value.

uated excretory pore, a relatively longer spicule and a relatively shorter gubernaculum in the males, plus relatively smaller eggs (Table 1) and more developed cervical alae, which are strongly curved dorsally, in the females. We consider, therefore, that our specimens are new to science.

\section{Acknowledgements}

This work was supported in part by NATO Grant No. CRG 920612 and National Science Foundation Grant Numbers BSR8612329 and BSR-9024816 to Scott L. Gardner. 


\section{References}

Hugot, J.-P. (1983) Redescription d'Helminthoxys tiflophila et considération sur la systématique des Oxyuridae parasites de Rongeurs. Annales de Parasitologie Humaine et Comparée, 58, 255-265.

Hugot, J.-P. (1986) Etude morphologique d'Helminthoxys urichi (Oxyurata, Nematoda), parasite de Dasyprocta aguti (Caviomorpha, Rodentia). Bulletin du Muséum National d'Histoire Naturelle, Série 4, 8, 133-138.

Hugot, J.-P. (1988) Les nématodes Syphaciinae parasites de Rongeurs et de Lagomor- phes. Taxonomie. Zoogéographie. Evolution. Mémoires du Muséum National d'Histoire Naturelle, Série A, Zoologie, 141, 1-153. Hugot, J.-P. \& Sutton, C.A. (1989) Etude morphologique de deux oxyures appartenant au genre Helminthoxys. Bulletin du Muséum National d'Histoire Naturelle, Série 4, 9, 387-395.

Sutton, C.A. \& Hugot, J.-P. (1993) First record of Helminthoxys gigantea (Quentin, Courtin \& Fontecilla, 1975) (Nematoda: Oxyurida) in Argentina. Research $\mathcal{E}$ Reviews in Parasitology, 53, 141-142. 